Research article

\title{
c-erbB2 and topoisomerase II $\alpha$ protein expression independently predict poor survival in primary human breast cancer: a retrospective study
}

\author{
Peter Fritz ${ }^{1}$, Cristina M Cabrera ${ }^{2}$, Jürgen Dippon ${ }^{3}$, Andreas Gerteis ${ }^{4}$, Wolfgang Simon ${ }^{4}$, \\ Walter E Aulitzky ${ }^{5}$ and Heiko van der Kuip²
}

\author{
1Department of Diagnostic Medicine, Pathology, Robert Bosch Hospital, Stuttgart, Germany \\ ${ }^{2}$ Dr Margarete Fischer-Bosch Institute of Clinical Pharmacology, Stuttgart, Germany \\ ${ }^{3}$ Department of Mathematics, University of Stuttgart, Stuttgart, Germany \\ ${ }^{4}$ Department of Gynaecology, Robert Bosch Hospital, Stuttgart, Germany \\ ${ }^{5}$ 2nd Department of Internal Medicine, Oncology and Hematology, Robert Bosch Hospital, Stuttgart, Germany \\ Corresponding author: Heiko van der Kuip, heiko.van-der-kuip@ikp-stuttgart.de
}

Received: 1 Jan 2004 Revisions requested: 27 Oct 2004 Revisions received: 7 Feb 2005 Accepted: 23 Feb 2005 Published: 21 Mar 2005

Breast Cancer Research 2005, 7:R374-R384 (DOI 10.1186/bcr1012)

This article is online at: http://breast-cancer-research.com/content/7/3/R374

(c) 2005 Fritz et al; licensee BioMed Central Ltd.

This is an Open Access article distributed under the terms of the Creative Commons Attribution License (http://creativecommons.org/licenses/by/ 2.0), which permits unrestricted use, distribution, and reproduction in any medium, provided the original work is properly cited.

\begin{abstract}
Introduction c-erbB2 (also known as HER-2/neu) and topoisomerase $\| \alpha$ are frequently overexpressed in breast cancer. The aim of the study was to analyze retrospectively whether the expression of c-erbB2 and topoisomerase $\| \alpha$ protein influences the long-term outcome of patients with primary breast cancer.
\end{abstract}

Methods In this study c-erbB2 and topoisomerase Il $\alpha$ protein were evaluated by immunohistochemistry in formalin-fixed paraffin-embedded tissue from 225 samples of primary breast cancer, obtained between 1986 and 1998. The prognostic value of these markers was analyzed.

Results Of 225 primary breast tumor samples, 78 (34.7\%) showed overexpression of either c-erbB2 (9.8\%) or topoisomerase $I l \alpha$ protein (24.9\%), whereas in 21 tumors
(9.3\%) both proteins were found to be overexpressed. Patients lacking both c-erbB2 and topoisomerase ll $\alpha$ overexpression had the best long-term survival. Overexpression of either c-erbB2 or topoisomerase Il $\alpha$ was associated with shortened survival, whereas patients overexpressing both c-erbB2 and topoisomerase Il $\alpha$ showed the worst disease outcome $(P<$ $0.0001)$. Treatment with anthracyclines was not capable of reversing the negative prognostic impact of topoisomerase Il $\alpha$ or c-erbB2 overexpression.

Conclusion The results of this exploratory study suggest that protein expression of c-erbB2 and topoisomerase Il $\alpha$ in primary breast cancer tissues are independent prognostic factors and are not exclusively predictive factors for anthracycline response in patients with primary breast cancer.

\section{Introduction}

The protein expression status of c-erbB2 and, more recently, of topoisomerase Il $\alpha$ has been implicated in the prediction of clinical outcome and response to chemotherapy in breast cancer [1-5]. Gene amplification is the predominant but not exclusive mechanism causing abnormal expression in these tumors (reviewed in [6]). c-erbB2 is localized on chromosome 17q1221 and encodes for a transmembrane tyrosine kinase receptor protein. This highly glycosylated protein is a member of the epidermal growth factor receptor (EGFR; HER) family [7] and is expressed on most cells of epithelial origin. In vitro, overexpression of c-erbB2 in epithelial cells ultimately affects the reg- ulation of cell proliferation, of apoptotic pathways, of motility, and of adhesion (overview in [8]). Accordingly, numerous studies have found that both $c$-erbB2 amplification and c-erbB2 protein overexpression predicted disease outcome in patients with localized breast cancer (overview in [9]).

The $\alpha$ isoform of topoisomerase is a key enzyme in DNA replication and also a target for various chemotherapeutic agents such as anthracyclines or epipodophyllotoxins. The gene is located in close proximity to the c-erbB2 gene on chromosome 17q21 and encodes for a 170-kilodalton protein. The enzyme catalyzes the unwinding of the DNA to a partly 
uncoiled form by inducing single-stranded breaks on both DNA strands. These breaks allow the passage of doublestranded DNA through the gap [10]. Anthracyclines, one of the most widely used class of cytotoxic agents for the treatment of breast cancer, inhibit topoisomerase Il $\alpha$ by trapping the DNA strand break intermediates, leading to persistent DNA cleavage.

An important role for the outcome of patients with breast cancer has been proposed both for the c-erbB2 and topoisomerase Il $\alpha$ protein [11]. Interestingly, a high percentage of primary breast tumors with c-erbB2 amplification also show a gene copy number alteration of other genes such as topoisomerase $1 / \alpha$ located near to the c-erbB2 locus on chromosome 17 $[12,13]$. Although the appearance of topoisomerase // $\alpha$ gene alterations (amplification or deletion) was exclusively seen in $c^{-}$ erbB2-amplified breast tumors [3,12-14], data on the protein expression status of these two genes in breast tumor samples are controversial. Jarvinen and colleagues report a high correlation of c-erbB2 and topoisomerase Il $\alpha$ protein expression [15]. In contrast, in a recently published study it was observed that in 14 of 33 topoisomerase $/ / \alpha$-amplified tumors, topoisomerase Il $\alpha$ protein was present in less than $10 \%$ of tumor cells [16]. Another study showed that topoisomerase ll $\alpha$ overexpression is present in 30\% of c-erbB2 non-amplified tumors [17]. From these studies it has to be concluded that gene amplification is only one of many mechanisms causing high intracellular levels of the topoisomerase Il $\alpha$ protein. This is in concordance with the fact that expression of topoisomerase $\| \alpha$ is regulated on multiple levels, including transcriptional, translational, and post-translational mechanisms [18]. These data suggest that the expression of topoisomerase Il $\alpha$ and cerbB2 protein might independently predict the clinical outcome in breast cancer. We therefore analyzed the prognostic impact of the protein expression status of both c-erbB2 and topoisomerase $\| \alpha$ in a large cohort of patients with primary breast cancer.

\section{Materials and methods Patients and pathological data}

Tumor tissue was analyzed for protein expression of c-erbB2 and topoisomerase Il $\alpha$ from 225 patients with primary invasive breast cancer who underwent surgery from 1986 to 1998 at the Department of Gynaecology, Robert Bosch Hospital, Stuttgart, Germany. The local ethics committee was informed and gave consent. The patient database was anonymized to guarantee privacy. The tissues were formalin-fixed and paraffin-embedded in accordance with standard methods. Histological classification was performed by following the recommendations of the World Health Organization [19]. Three histological types were discriminated: invasive ductal, invasive lobular, and all other specified tumor types such as tubular carcinoma. The pathological reports included tumor size, palpable nodes, metastasis, grading, estrogen receptor status, and progesterone receptor status.

\section{Immunohistochemical methods}

For immunocytochemistry, $3 \mu \mathrm{m}$ sections were deparaffinized in xylene for 30 min and rinsed in 100\%, 96\% and 70\% ethanol. Sections were then subjected to antigen retrieval by immersion in citrate buffer $\left(\mathrm{pH}\right.$ 6.0) preheated to $99^{\circ} \mathrm{C}$ for 40 min. Endogenous peroxidase was blocked by incubation in $3 \% \mathrm{H}_{2} \mathrm{O}_{2}$ in methanol for $30 \mathrm{~min}$, followed by rinsing in Trisbuffered saline containing Tween 20. Immunohistochemical staining was performed with the $\mathrm{EnVision}^{\mathrm{TM}}+$ System Kit (DakoCytomation, Glostrup, Denmark). Afterwards, the sections were incubated overnight in a humidity chamber with the monoclonal primary antibody against topoisomerase $\| \alpha$ (DakoCytomation; dilution 1:100) and c-erbB2 (clone CB11; Novocastra, Newcastle, UK; dilution 1:10) followed by incubation for 30 min with a dextran polymer conjugated with horseradish peroxidase enzyme and with goat anti-rabbit antibody. The antigen-antibody immunoreaction was revealed with 3,3'diaminobenzidinetetrahydrochloride as the chromogen, and the slides were counterstained with hematoxylin.

Immunohistochemical analysis of c-erbB2 (HER-2/neu) protein was also performed with HercepTest ${ }^{\mathrm{TM}}$ (DakoCytomation) on an automated immunostaining system (Dako Autostainer), with the use of the manufacture's detection procedures. This procedure was part of the primary diagnostic process. For each case c-erbB2 was assessed twice: once by immunostaining with $\mathrm{CB} 11$ and once by herceptin staining. Estrogen and progesterone receptor statuses were assessed during the first years (up to 1990) by charcoal dextran method [20], samples examined after this time were analyzed by immunohistochemistry.

\section{Scoring interpretation}

The scoring system proposed by HercepTest was used for the interpretation of the immunoreactivity of both CB11 and HercepTest, distinguishing between no staining (0), weakly $(1+)$, moderate $(2+)$, and strong membrane staining $(3+)$. Cytoplasmic staining was ignored.

Only nuclear staining was considered for topoisomerase II $\alpha$. Immunostaining frequency of the tumor cells was scored subjectively on a scale of 1 to 4 (1, 0 to $5 \%$ positive tumor cells; 2,6 to $25 \%$; 3, 26 to $75 \% ; 4$, more than 75\%), as proposed by Sandri and colleagues [21]. Finally, after cut-off analysis we stratified the results as negative for less than $25 \%$ tumor cells and positive for all cases in which more than $25 \%$ of tumor cells stained positive for topoisomerase Il $\alpha$. For hormone receptor status we classified the tumor as positive if there was more than $15 \mathrm{fmol}$ per $\mathrm{mg}$ of protein (charcoal dextran method) or with a score of more than 1 (immunohistochemistry).

\section{Statistical methods}

Descriptive statistical analysis was performed with commercially available software packages (SPSS, version 11.1 
Table 1

\begin{tabular}{lc}
\hline Characteristics of patients and tumors & Value \\
\hline Characteristic & 225 \\
\hline Number of patients & $56(29-88)$ \\
Age, years (median (range)) & $25(0-179)$ \\
Time to relapse, months (median (range))a & 123 \\
Alive without disease & 23 \\
Relapse & 3 \\
Disease status unknown & 136 \\
Alive (censored) & 89 \\
Death & 68 \\
By tumor & 8 \\
By unknown causes & 13 \\
$\quad$ Not tumor-related (censored) & 39 \\
\hline
\end{tabular}

aOnly cases with recurrence are included in this calculation.

(SPSS GmbH, Munich, Germany) and R, version 2.0 http:// www.r-project.org). We used the Kaplan-Meier estimator for univariate statistical analysis and the Cox regression model for multivariate analysis. $P<0.05$ was considered to be significant. A log-rank test was applied for assessing statistical differences between survival curves. The $\chi^{2}$ test was used to investigate the relationship between topoisomerase $\| \alpha$ expression and histological grading and to analyze the association between topoisomerase $\mathrm{Il} \alpha$ and c-erbB2 overexpression with hormone receptor status or stage.

\section{Results \\ Patients}

Tissue samples of 225 patients were analyzed for protein expression of c-erbB2 or topoisomerase Il $\alpha$. The characteristics of these patients and tumors are summarized in Table 1. The distribution of stage, tumor size, nodal status, histological grading, and receptor status is in conformity with that observed in published randomized clinical trials (Table 2; reviewed in [22]). All patients had received appropriate local surgical treatment. Adjuvant medical therapy was given to 143 patients: 61 received hormone therapy; 82 were treated with adjuvant chemotherapy, either anthracycline-containing (46 patients) or anthracycline-free (36 patients; Table 3) regimens. After a mean follow-up period of 67 months, 136 patients were alive and 89 deaths had been recorded. The death of 68 patients (30\%) was documented to have been caused by breast cancer (Table 1). Survival at 1 year was $95.73 \%$, at 3 years $85.45 \%$, at 5 years $74.26 \%$, and at 10 years $63.69 \%$ for all patients. Again, this survival rate is comparable to that published for similar patient populations [22].

\section{Prognostic impact of c-erbB2 overexpression}

Tumors with an immunoreactive score exceeding 2 or 3 were considered to overexpress c-erbB2. Accordingly, 43 (19.1\%) of the patients showed overexpression of this oncogene. Patients with c-erbB2 overexpression showed a similar distribution of age, stage, histological criteria, and receptor status to that of the c-erbB2 negative subgroup (data not shown).

However, the former patients were characterized by a significantly inferior survival in a univariate statistical analysis (log rank $17.94 ; P<0.0001)$. The median overall survival time of patients with tumors overexpressing c-erbB2 was 55 months, with a 5 -year survival rate of $46.0 \%$. In contrast, median survival time was not reached in the c-erbB2 negative group. The 5 -year survival in this group was $78.3 \%$ (Fig. 1a). Patients with c-erbB2-overexpressing tumors received no significant benefit from anthracycline-based adjuvant therapy, and even had the worst prognosis of all groups analyzed (log rank 10.17; $P=$ 0.001 ; see below).

\section{Impact of topoisomerase Il $\alpha$ expression}

Topoisomerase Il $\alpha$ staining was strictly nuclear and highly variable between different tissue samples. To study the impact of different levels of overexpression of topoisomerase Il $\alpha$ protein, we analyzed the survival curves of patients with 0 to $5 \%, 6$ to $25 \%, 26$ to $75 \%$ and more than $75 \%$ positively stained cells (data not shown). These analyses demonstrated that the survival of patients was significantly inferior in cases with high topoisomerase Il $\alpha$ expression in more than $25 \%$ of the cells. Therefore, for further analysis overexpression was defined as more than $25 \%$ positively stained tumor cells. A subgroup of 77 patients (34.2\%) had tumors overexpressing topoisomerase Il $\alpha$. As shown in Fig. 1b, these patients had a significantly inferior survival (median 80 months; 5-year survival rate 
(a)

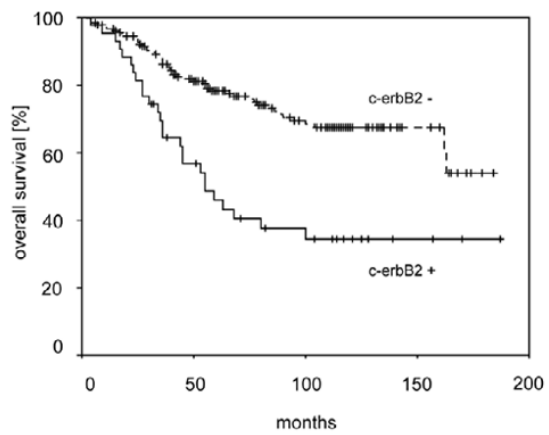

(b)

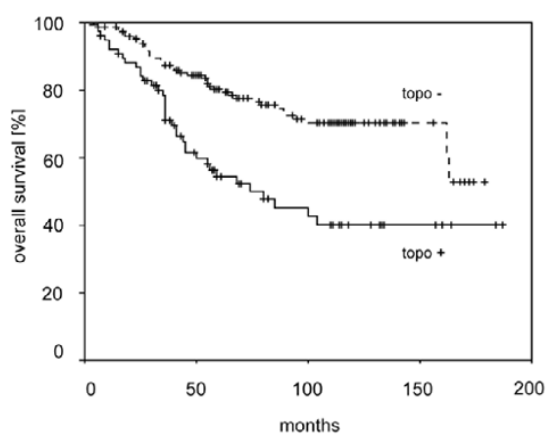

Overall survival of breast cancer patients with regard to c-erbB2 and topoisomerase ll $\alpha$ protein expression. (a) Patients with (solid line) or without (dashed line) c-erbB2 protein overexpression. The difference was significant in univariate statistical analysis (log rank 17.94; $P<0.0001)$. (b) Significant difference of survival time of patients with tumors positive for topoisomerase ll $\alpha$ protein in more than $25 \%$ of tumor cells (solid line) versus patients with tumors with less than 25\% topoisomerase ll $\alpha$-positive cells (dashed line) (log rank 15.59; $P=0.0001$ ).

$54.4 \%)$ in a univariate Kaplan-Meier analysis compared with those without topoisomerase Il $\alpha$ overexpression (median not reached; 5-year survival rate $80.3 \%$; log rank $15.59, P=$ $0.0001)$. The proportion of tumors expressing topoisomerase $\| \alpha$ increased with histological grading ( $\chi^{2}$ test, $P<0.001$ ). The fraction of patients with hormone-receptor-positive tumors was significantly higher in samples without topoisomerase Il $\alpha$ overexpression ( $\chi^{2}$ test, $\left.P=0.004\right)$.

The prognostic impact of topoisomerase Il $\alpha$ expression was dependent on stage: whereas stage IV patients had an identically poor outcome regardless of topoisomerase Il $\alpha$ expression (not shown), stage II and III patients had a significantly lower survival rate when topoisomerase Il $\alpha$ was highly expressed (log rank 9.35, $P=0.002$ for WHO stage II; log rank 4.76, $P=0.029$ for $\mathrm{WHO}$ stage III; Fig. 2a). In stage I patients a survival difference of similar magnitude was not statistically significant, probably because of the small sample size (Fig. 2a).

Expression of topoisomerase ll $\alpha$ added prognostic information to histological grading. The analysis was restricted to grade 2 and 3 tumors, because only a few deaths were observed in patients with grade 1 disease. The survival of patients with tumors expressing topoisomerase $\| \alpha$ was inferior in both grade 2 tumors (log rank 5.08; $P<0.05$ ) and grade 3 tumors (log rank 7.86; $P=0.005$; Fig. 2b).

In addition, the prognostic impact of topoisomerase ll $\alpha$ expression was clearly dependent on the steroid hormone receptor status of the tumors: no significant difference was observed in patients with tumors negative for estrogen or progesterone receptor (log rank 0.94; $P=0.33$; Fig. 3, right panel) whereas detection of topoisomerase $\| \alpha$ in more than $25 \%$ of tumor cells identified a subgroup with poor prognosis in receptor- positive breast cancer (log rank 12.0; $P=0.0005$; Fig. 3, left panel).

We further studied whether the prognostic impact of topoisomerase Il $\alpha$ expression was restricted to patients receiving either non-anthracycline-containing or anthracycline-containing regimens for adjuvant treatment. By analogy with the results obtained with c-erbB2-overexpressing tumors (Fig. $4 b)$, treatment with anthracyclines was not capable of reversing the negative prognostic impact of topoisomerase Il $\alpha$ expression (log rank 4.74; $P=0.02$; Fig. 4a).

\section{Coexpression of c-erbB2 and topoisomerase II $\alpha$}

The subgroups overexpressing c-erbB2 and topoisomerase Il $\alpha$ were overlapping but not identical. One hundred and twenty-six tumors (56\%) showed neither c-erbB2 nor topoisomerase Il $\alpha$ overexpression. Fifty-six (25\%) patients had tumors overexpressing topoisomerase Il $\alpha$ only; 22 (9.8\%) showed only c-erbB2 overexpression. Twenty-one (9.3\%) tumors showed increased staining for both proteins. None of these groups differed significantly with regard to clinical stage (Table 4). However, a statistically significantly higher proportion of hormone-receptor-negative cancers was observed in the group overexpressing one or both proteins studied $\left(\chi^{2}\right.$ test, $P=0.006$; Table 4). A survival analysis of these four groups demonstrated an independent negative prognostic impact of either overexpression. As shown in Fig. 5, patients with breast cancer lacking overexpression of both c-erbB2 and topoisomerase Il $\alpha$ had the best long-term prognosis (the median survival time was not reached; the 5-year survival rate was $84.4 \%$ ). Overexpression of either c-erbB2 or topoisomerase Il $\alpha$ was associated with intermediate survival (for c-erbB2overexpressing tumors the median survival time was 68 months and the 5-year survival rate was $57.7 \%$; for topoisomerase Il $\alpha$-overexpressing cases the median survival time was 104 months and the 5-year survival rate was 63.7\%). 
Figure 2

(a) WHO stage I

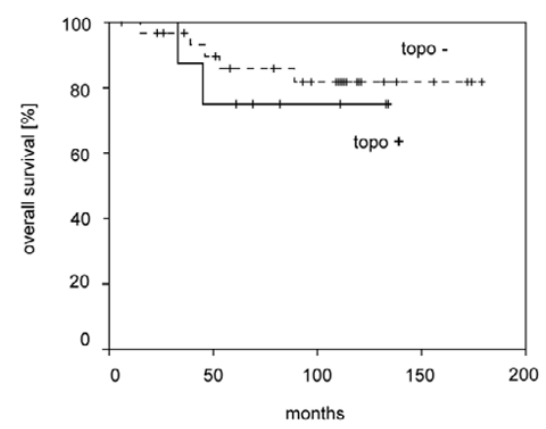

WHO stage II

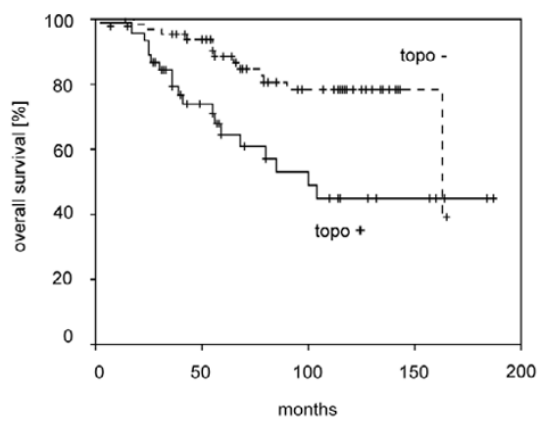

WHO stage III

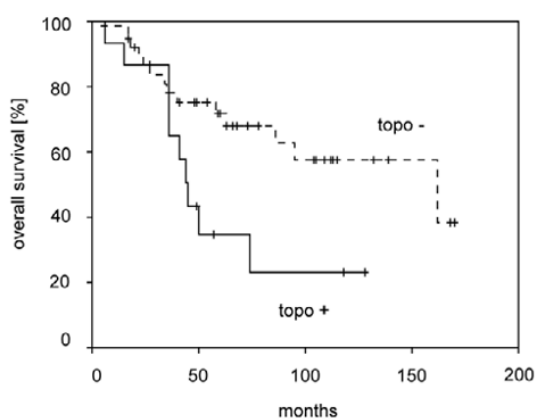

(b)

\section{Grade 2}

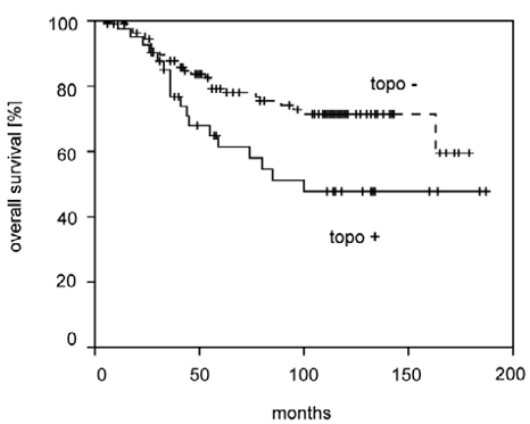

Grade 3

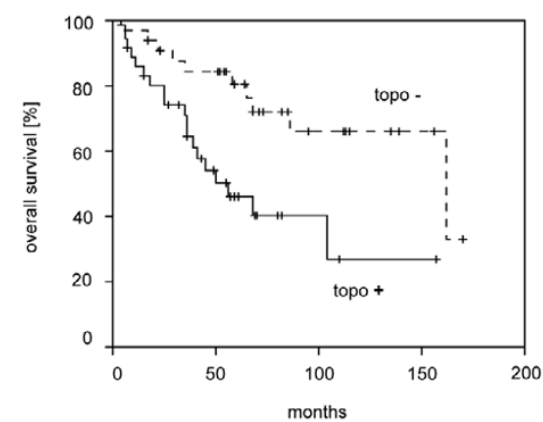

Prognostic impact of topoisomerase ll $\alpha$ protein expression with regard to stage and grading. Patients with tumors positive for topoisomerase ll $\alpha$ in more than $25 \%$ of tumor cells (solid lines) were compared with those having tumors expressing topoisomerase ll $\alpha$ in less than $25 \%$ of cells (dashed lines) with regard to the stage (a) and the grading (b) of the tumor. The difference was significant in tumors of stage 2 and $3(P<0.05)$ and in grade 2 and 3 tumors $(P<0.05)$.

Figure 3

ER or PR positive

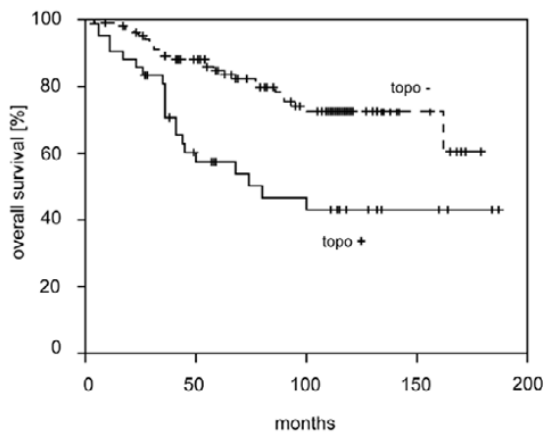

ER and PR negative

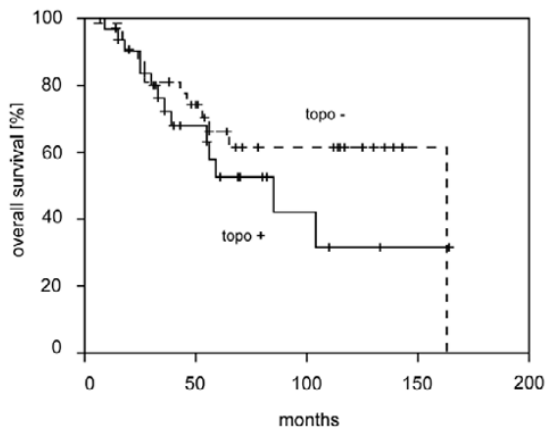

Prognostic impact of topoisomerase ll $\alpha$ protein expression with regard to hormone status. Patients with tumors positive for topoisomerase ll $\alpha$ in more than $25 \%$ of tumor cells (solid lines) were compared with those having tumors expressing topoisomerase ll $\alpha$ in less than $25 \%$ of cells (dashed lines) with regard to the hormone status. The difference was significant in tumors positive for estrogen receptor or progesterone receptor (log rank $12.0 ; P=0.0005)$. 
Table 2

Clinical characteristics of study patients $(N=225)$

\begin{tabular}{|c|c|}
\hline Variable & $n(\%)$ \\
\hline \multicolumn{2}{|l|}{ Stage $(n=214)$} \\
\hline I & $40(18.7)$ \\
\hline II & $113(52.8)$ \\
\hline III & $53(24.8)$ \\
\hline IV & $8(3.7)$ \\
\hline \multicolumn{2}{|l|}{$\mathrm{T}(n=222)$} \\
\hline $\mathrm{T} 1$ & $59(26.6)$ \\
\hline $\mathrm{T} 2$ & $106(47.7)$ \\
\hline Т3 & $27(12.2)$ \\
\hline $\mathrm{T} 4$ & $30(13.5)$ \\
\hline \multicolumn{2}{|l|}{$\mathrm{N}(n=222)$} \\
\hline No & $94(42.3)$ \\
\hline N1 & $112(50.5)$ \\
\hline $\mathrm{N} 2-3$ & $16(7.2)$ \\
\hline \multicolumn{2}{|l|}{ Grading $(n=220)$} \\
\hline $\mathrm{G} 1 / \mathrm{G} 2$ & $151(68.6)$ \\
\hline G3 & $69(31.4)$ \\
\hline \multicolumn{2}{|l|}{ Histology $(n=225)$} \\
\hline Ductal & $175(77.8)$ \\
\hline Lobular & $22(9.8)$ \\
\hline All other subtypes & $28(12.4)$ \\
\hline \multicolumn{2}{|l|}{ Menopausal $(n=163)$} \\
\hline Premenopausal & $43(26.4)$ \\
\hline Postmenopausal & $120(73.6)$ \\
\hline \multicolumn{2}{|l|}{$\mathrm{ER}(n=212)$} \\
\hline Positive & $135(63.7)$ \\
\hline Negative & 77 (36.3) \\
\hline \multicolumn{2}{|l|}{$\operatorname{PR}(n=211)$} \\
\hline Positive & $127(60.2)$ \\
\hline Negative & $84(39.8)$ \\
\hline \multicolumn{2}{|l|}{ Metastasis $(n=218)$} \\
\hline Negative & $210(96.3)$ \\
\hline Positive & $8(3.7)$ \\
\hline
\end{tabular}

ER, estrogen receptor; N, palpable nodes; PR, progesterone receptor; $T$, tumor size.

Those patients overexpressing both proteins had the worst outcome, with a median survival of 45 months and a 5-year survival rate of $33.0 \%$ (log rank $29.71 ; P<0.0001$; Fig. 5).
In a multivariate Cox regression model (Tables 5 and 6), tumor stage, estrogen receptor, topoisomerase Il $\alpha$, and c-erbB2 all independently predicted disease-related death. Subsequent 
Table 3

Medical treatment for primary breast cancer in the study patients $(N=198)$

\begin{tabular}{llc}
\hline Therapy type & Intervention & $n(\%)$ \\
\hline Adjuvant hormone therapy & No hormone therapy & $137(69.2)$ \\
& Tamoxifen & $61(30.8)$ \\
Adjuvant chemotherapy & Anthracycline-containing regimens & $46(23.2)$ \\
& Anthracycline-free regimens & $36(18.2)$ \\
& No chemotherapy & $116(58.6)$ \\
& No adjuvant therapy & $55(27.8)$
\end{tabular}

Figure 4

(a) non-anthracycline based therapy

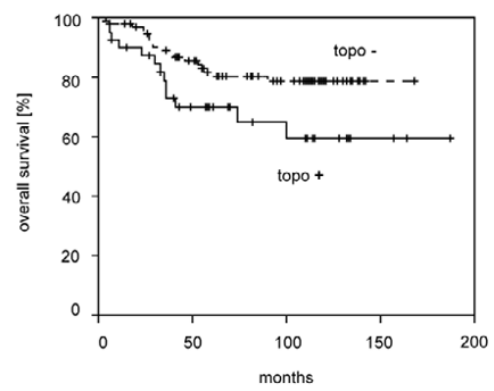

(b) non-anthracycline based therapy

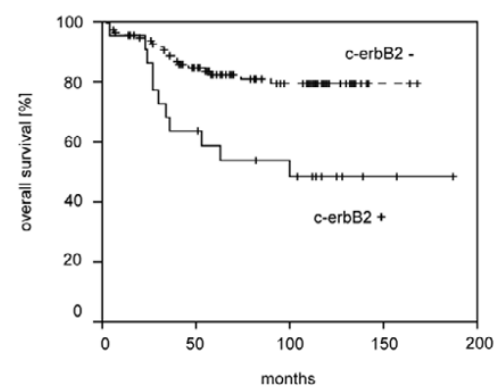

anthracycline based therapy

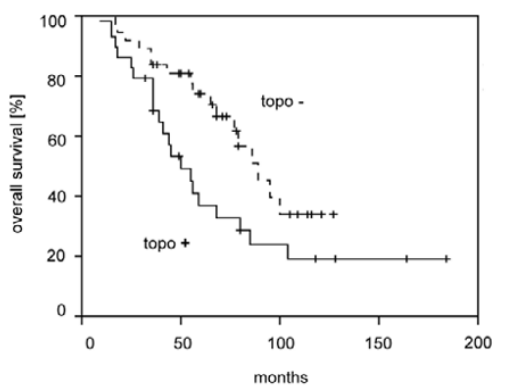

anthracycline based therapy

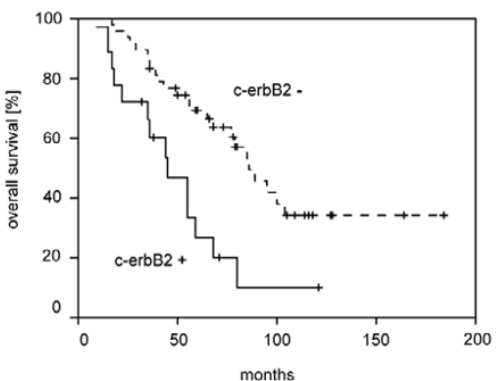

Survival of patients receiving either non-anthracycline-based therapy or anthracycline-based chemotherapy. (a) The difference between patients with less than $25 \%$ positive cells for topoisomerase Il $\alpha$ (dashed lines) and more than $25 \%$ positive cells (solid lines) was significant for both patient groups $(P<0.05)$. (b) Significant difference between patients with (solid line) or without (dashed line) c-erbB2 overexpression in the group of patients receiving non-anthracycline-based adjuvant therapy (left panel; $P=0.002$ ) or an anthracycline-containing regimen (right panel; $P=0.001$ )

inclusion of grading was far beyond statistical significance (Table 5). Adding the interaction term topoisomerase Il $\alpha$ by grading (topoisomerase Il $\alpha \times$ grading; Table 5) seems worth consideration. However, in a Wald statistics grading together with the last-mentioned interaction term failed to reach significance $(P=0.11)$. Models containing in addition interactions of c-erbB2 by grading (c-erbB2 $\times$ grading; Table 5 ) and cerbB2 by topoisomerase $\| \alpha$ (c-erbB2 $\times$ topoisomerase $\| \alpha$; Table 5) are not significantly superior. The last two interaction terms are therefore not included in the final model as presented in Table 6.

\section{Discussion}

Overexpression of c-erbB2 and topoisomerase Il $\alpha$ independently predicts poor survival in this retrospective series of patients. Topoisomerase $\mathrm{Il} \alpha$ and c-erbB2 were found to be overexpressed in overlapping but distinct subgroups of patients. Moreover, the prognostic impact of topoisomerase Il $\alpha$ overexpression seems to be independent of other prognostic variables in a multivariate analysis and makes the prognosis significantly worse in both c-erbB2-positive and c-erbB2-negative patients. In addition, the prognostic impact of topoisomerase Il $\alpha$ overexpression is dependent on the steroid receptor status. The results of this study suggest that 
Table 4

Clinical characteristics of patients with and without overexpression of c-erbB2 and topoisomerase Il $\alpha$

\begin{tabular}{|c|c|c|c|c|}
\hline \multirow{3}{*}{$\begin{array}{l}\text { Parameter } \\
\text { Topoisomerase overexpression } \\
\text { C-erb B2 overexpression }\end{array}$} & \multicolumn{4}{|c|}{ Value } \\
\hline & Absent & Absent & Present & Present \\
\hline & Absent & Present & Absent & Present \\
\hline \multicolumn{5}{|l|}{ Stage, $n(\%)$} \\
\hline 1 & $29(24.2)$ & $3(15.0)$ & $6(11.1)$ & $2(10.0)$ \\
\hline II & $59(49.1)$ & $7(35.0)$ & $36(66.6)$ & $11(55.0)$ \\
\hline III & $29(24.2)$ & $9(45.0)$ & $9(16.7)$ & $6(30.0)$ \\
\hline IV & $3(2.5)$ & $1(5)$ & $3(5.6)$ & $1(5.0)$ \\
\hline Total ${ }^{a}$ & 120 & 20 & 54 & 20 \\
\hline \multicolumn{5}{|l|}{ Receptor status, $n(\%)$} \\
\hline ER or PR positive & $92(79.3)$ & $12(57.1)$ & $32(58.2)$ & $10(52.6)$ \\
\hline PR and PR negative & $24(20.7)$ & $9(42.9)$ & $23(41.8)$ & $9(47.4)$ \\
\hline Totalb & 116 & 21 & 55 & 19 \\
\hline
\end{tabular}

a214 patients with complete data were analyzed for stage; b211 patients with complete data were analyzed for receptor status. ER, estrogen receptor; PR, progesterone receptor.

\section{Figure 5}

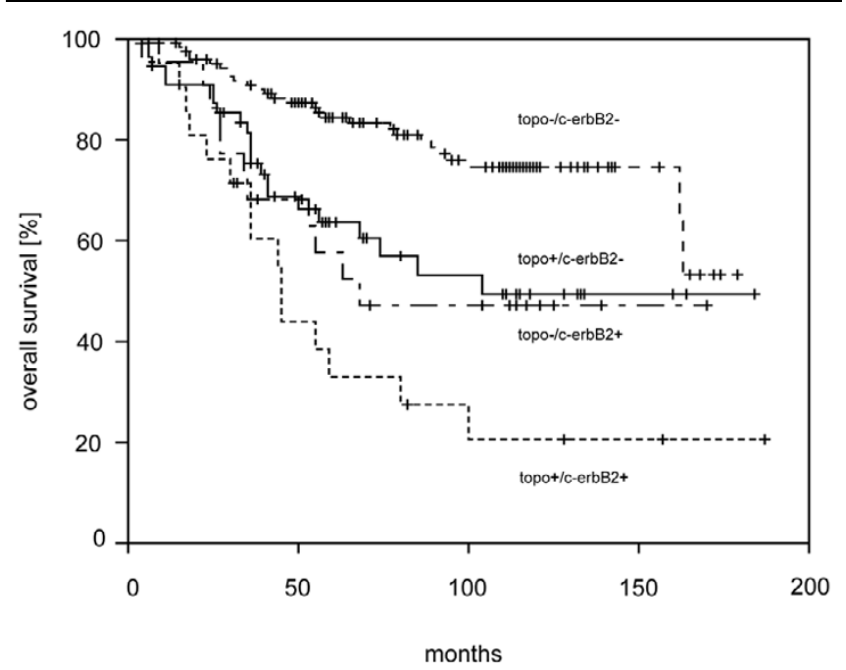

Survival of patients with and without overexpression of c-erbB2 and topoisomerase Il $\alpha$. The difference between patients without overexpression of c-erbB2 or topoisomerase (broken line), patients with tumors overexpressing one of the two proteins (c-erbB2, dot-dashed line; topoisomerase Il $\alpha$, solid line), and patients with tumors overexpressing both c-erbB2 and topoisomerase ll $\alpha$ (dotted line) was significant (log rank 29.71; $P<0.0001)$.

anthracycline treatment is not capable of reversing the negative prognostic influence of topoisomerase $\| \alpha$ or c-erbB2 expression.

Recent reports have studied the interaction between topoisomerase Il $\alpha$ expression and pathological variables, chemotherapy response, and the proliferation rate of breast cancer.
However, only very limited series reported a long-term outcome of patients with primary breast cancer depending on topoisomerase Il $\alpha$. Di Leo and colleagues [2] studied patients participating in a randomized clinical trial comparing CMF (cyclophosphamide, methotrexate, and 5-flourouracil) with an anthracycline-containing regimen. The subgroup of patients with topoisomerase $/ / \alpha$ amplification did not do obviously more badly than the remaining patients. However, the outcome was strongly dependent on the adjuvant therapy applied. Another series measuring topoisomerase Il $\alpha$ protein by immunohistochemistry showed a significantly adverse influence of topoisomerase ll $\alpha$ expression of a similar magnitude to that in our study [23]. Durbecq and colleagues [16] have shown that measurement of protein expression and gene amplification each identify different subsets of patients. These data suggest that detection of the protein might be better correlated with the biological properties of the tumor and therefore might predict the clinical outcome more precisely than genetic analysis. The data in our study support the view that protein expression of topoisomerase Il $\alpha$ is a relevant factor predicting long-term prognosis in patients with newly diagnosed breast cancer independent of c-erbB2.

Treatment of cell lines with anthracyclines was less effective in cells with a low expression of topoisomerase Il $\alpha$ [24,25]. A retrospective subgroup analysis of a randomized clinical trial suggests that the prognostic impact of topoisomerase $/ / \alpha$ gene amplification is restricted to the patients not receiving anthracycline-based chemotherapy [2]. Furthermore, other studies that related tumor response to anthracyclines also showed some correlation between gene amplification status of topoisomerase $/ / \alpha$ and clinical response [3-5]. This is in contrast 
Table 5

\begin{tabular}{|c|c|c|c|}
\hline Stepwise inclusion of variable & $2 \times$ increase in partial log-likelihood $\left(\chi^{2}\right.$ distributed) & df & $P$ \\
\hline Stage & 23.43 & 3 & $<0.0001$ \\
\hline Estrogen receptor & 7.92 & 1 & 0.005 \\
\hline c-erbB2 & 7.34 & 1 & 0.01 \\
\hline Topoisomerase Il $\alpha$ & 9.85 & 1 & 0.002 \\
\hline Grading & 0.01 & 1 & 0.92 \\
\hline Topoisomerase ll $\alpha \times$ grading & 4.64 & 1 & 0.03 \\
\hline c-erbB2 $\times$ grading & 1.74 & 1 & 0.19 \\
\hline c-erbB2 $\times$ topoisomerase Il $\alpha$ & 0.17 & 1 & 0.68 \\
\hline
\end{tabular}

Starting from the null model, successive adding of the variables mentioned above improves the Cox proportional hazard model in the first four steps significantly. In this sense the first four variables can be considered as independent prognostic factors. df, degrees of freedom.

Table 6

Coefficients of the linear predictor in the final Cox regression model $(N=196)$

\begin{tabular}{|c|c|c|c|c|}
\hline Variable & $B$ & $\exp (B)$ & $P$ & $95 \% \mathrm{Cl}$ for $\exp (B)$ \\
\hline \multicolumn{5}{|l|}{ Stage } \\
\hline$\| \mathrm{a}$ & 0.72 & 2.06 & 0.14 & $0.79-5.36$ \\
\hline IIIa & 1.69 & 5.4 & 0.001 & $1.97-14.74$ \\
\hline IVa & 3.25 & 25.68 & $<0.001$ & $6.72-98.17$ \\
\hline Estrogen receptor (pos. versus neg.) & 0.58 & 1.79 & 0.039 & $1.03-3.11$ \\
\hline c-erbB2 (pos. versus neg.) & 0.82 & 2.26 & 0.0036 & $1.31-3.93$ \\
\hline Topoisomerase Il $\alpha$ (pos. versus neg.) & 0.39 & 1.48 & 0.005 & $0.77-2.83$ \\
\hline Grading (3 versus $\{1,2\})$ & t0.62 & 0.54 & 0.15 & $0.23-1.25$ \\
\hline Topoisomerase $\| l \alpha \times$ grading $^{b}$ & 1.21 & 3.35 & 0.035 & $1.09-10.36$ \\
\hline
\end{tabular}

aThe hazard ratio $\exp (B)$ of the stage given is the relative risk of this stage with respect to stage l. bThe effect of the interaction term on survival can be described as follows: if grading equals G1 or G2, the hazard ratio of topoisomerase ll $\alpha$ positive versus negative is 1.48 ( $95 \%$ confidence interval ( $\mathrm{Cl}) 0.77$ to 2.83 ); if grading equals $\mathrm{G} 3$, this hazard ratio is 4.96 (95\% $\mathrm{Cl} 2.00$ to 12.29$)$.

with a recently published retrospective study in which amplification of c-erbB2 and topoisomerase $/ / \alpha$ was not predictive of the response to anthracycline [26]. Our analyses show that the negative prognostic impact of topoisomerase Il $\alpha$ protein overexpression is observed both in patients who received an anthracycline-containing regimen for adjuvant chemotherapy and in those who did not. Moreover, the difference in survival between topoisomerase Il $\alpha$-positive and topoisomerase II $\alpha$ negative patients exceeds the proportion of patients expected to be cured by chemotherapy. Protein overexpression has been related to a variety of other molecular markers predictive for high proliferation rate or high grading of malignancy such as Ki67 expression or aneuploidy [16,23,26,27]. These findings support the view that overexpression of topoisomerase Il $\alpha$ protein indicates a poor prognosis irrespective of the therapy applied. Topoisomerase $/ / \alpha$ gene amplification is much more closely associated with c-erbB2 amplification than the protein expression status (overview in [6]). The predictive value of the gene amplification for clinical and long-term outcome might therefore be related to amplification of either or both of the c-erbB2 or topoisomerase I/ $\alpha$ genes. As coamplification is the predominant mechanism of genetic alteration of these two genes in breast cancer, clinical observations separate the role of each gene in the clinical response to adjuvant treatment with anthracyclines.

The biological role of topoisomerase $\| l \alpha$ overexpression is unknown. Cells lacking topoisomerases II are not capable of finishing a normal cell cycle and should therefore not be viable $[28,29]$. In addition, it has been shown that experimental overexpression of topoisomerase $\| \alpha$ in different human cell lines causes apoptosis [30]. From these observations one must conclude that cells staining with a low intensity are not cells with a complete lack of topoisomerase Il $\alpha$ function. This is in conformity with the observation that normal cells are also weakly positive for topoisomerase Il $\alpha$. High expression might 
be related to a high proliferation rate. This view is supported by our finding that topoisomerase $\| \alpha$ expression is related to histological grading and by observations showing some correlation of topoisomerase $\mathrm{Il} \alpha$ with Ki67 expression and other proliferation markers $[23,27]$. However, viable cells with constitutive overexpression might also indirectly indicate defects in apoptotic pathways. Both hypotheses might provide a plausible explanation for the observation that topoisomerase Il $\alpha$ overexpression is related to a more aggressive tumor phenotype.

\section{Conclusion}

Our data suggest that protein expression of topoisomerase Il $\alpha$ is a prognostic factor that is independent of c-erbB2, stage, and histological grading. In addition, the results of this exploratory study indicate that anthracycline treatment is not capable of reversing the negative prognostic influence of the expression of topoisomerase Il $\alpha$ or c-erbB2. Nevertheless, because of the small number of patients remaining in these subgroups, no firm conclusion can be made about the predictive value of topoisomerase $\| \alpha$ or c-erbB2 regarding sensitivity to anthracyclines. Our results support the view that studying the deregulation of either the topoisomerase // $\alpha$ gene or topoisomerase ll $\alpha$ protein might yield different results depending on the method applied. This should be considered when planning prospective studies on the predictive and prognostic value of topoisomerase $\| l \alpha$.

\section{Competing interests}

The author(s) declare that they have no competing interests.

\section{Authors' contributions}

PF, WS, WEA, JD, and HvdK were responsible for generating the hypothesis and correcting the manuscript. PF, AG, and WS were responsible for surgery and for collecting the patient material. PF, CMC, and HvdK were responsible for immunostaining and for examination and interpretation of the results. PF, JD, and WEA performed the statistical analysis of the data. PF, HvdK, and WEA were responsible for writing the manuscript. All authors read and approved the final manuscript.

\section{Acknowledgements}

We thank Monika McClellan, Susanne Gutzeit, and Kerstin Gawronski for technical assistance. This work was supported by a research grant from the Robert-Bosch foundation, project no. 11.5.8002.0004.1 (PF, CMC, WEA, HvdK).

\section{References}

1. Yu DH, Hung MC: Expression of activated rat neu oncogene is sufficient to induce experimental metastasis in $3 \mathrm{~T} 3$ cells. Oncogene 1991, 6:1991-1996.

2. Di Leo A, Gancberg D, Larsimont D, Tanner M, Jarvinen T, Rouas G, Dolci S, Leroy JY, Paesmans M, Isola J, Piccart MJ: HER-2 amplification and topoisomerase llalpha gene aberrations as predictive markers in node-positive breast cancer patients randomly treated either with an anthracycline-based therapy or with cyclophosphamide, methotrexate, and 5-fluorouracil. Clin Cancer Res 2002, 8:1107-1116.
3. Coon JS, Marcus E, Gupta-Burt S, Seelig S, Jacobson K, Chen S, Renta V, Fronda G, Preisler HD: Amplification and overexpression of topoisomerase llalpha predict response to anthracycline-based therapy in locally advanced breast cancer. Clin Cancer Res 2002, 8:1061-1067.

4. Park K, Kim J, Lim S, Han S: Topoisomerase II-alpha (topoll) and HER2 amplification in breast cancers and response to preoperative doxorubicin chemotherapy. Eur J Cancer 2003, 39:631-634.

5. Cardoso F, Durbecq V, Larsimont D, Paesmans M, Leroy JY, Rouas G, Sotiriou C, Renard N, Richard V, Piccart MJ, et al.: Correlation between complete response to anthracycline-based chemotherapy and topoisomerase II-alpha gene amplification and protein overexpression in locally advanced/metastatic breast cancer. Int J Oncol 2004, 24:201-209.

6. Di Leo A, Isola J: Topoisomerase II alpha as a marker predicting the efficacy of anthracyclines in breast cancer: are we at the end of the beginning? Clin Breast Cancer 2003, 4:179-186.

7. Stern DF, Heffernan PA, Weinberg RA: p185, a product of the neu proto-oncogene, is a receptorlike protein associated with tyrosine kinase activity. Mol Cell Biol 1986, 6:1729-1740.

8. Eccles SA: The role of c-erbB-2/HER2/neu in breast cancer progression and metastasis. J Mammary Gland Biol Neoplasia 2001, 6:393-406.

9. Ross JS, Fletcher JA, Linette GP, Stec J, Clark E, Ayers M, Symmans WF, Pusztai L, Bloom KJ: The Her-2/neu gene and protein in breast cancer 2003: biomarker and target of therapy. Oncologist 2003, 8:307-325.

10. Wang JC: Cellular roles of DNA topoisomerases: a molecular perspective. Nat Rev Mol Cell Biol 2002, 3:430-440.

11. Jarvinen TA, Liu ET: HER-2/neu and topoisomerase llalpha simultaneous drug targets in cancer. Comb Chem High Throughput Screen 2003, 6:455-470.

12. Keith WN, Douglas F, Wishart GC, McCallum HM, George WD, Kaye SB, Brown R: Co-amplification of erbB2, topoisomerase II alpha and retinoic acid receptor alpha genes in breast cancer and allelic loss at topoisomerase I on chromosome 20. Eur $J$ Cancer 1993, 29A:1469-1475.

13. Murphy DS, McHardy P, Coutts J, Mallon EA, George WD, Kaye $\mathrm{SB}$, Brown R, Keith WN: Interphase cytogenetic analysis of erbB2 and topoll alpha co-amplification in invasive breast cancer and polysomy of chromosome 17 in ductal carcinoma in situ. Int $J$ Cancer 1995, 64:18-26.

14. Jarvinen TA, Tanner M, Barlund M, Borg A, Isola J: Characterization of topoisomerase II alpha gene amplification and deletion in breast cancer. Genes Chromosomes Cancer 1999, 26:142-150

15. Jarvinen TA, Kononen J, Pelto-Huikko M, Isola J: Expression of topoisomerase Ilalpha is associated with rapid cell proliferation, aneuploidy, and c-erbB2 overexpression in breast cancer. Am J Pathol 1996, 148:2073-2082.

16. Durbecq V, Desmedt C, Paesmans M, Cardoso F, Di Leo A, Mano $M$, Rouas G, Leroy J-Y, Sotiriou C, Piccart M, et al:: Correlation between topoisomerase Ilalpha gene amplification and protein expression in Her-2 amplified breast cancer. Int $J$ Oncol 2004, 25:1473-1479.

17. Sotiriou C, Neo SY, McShane LM, Korn EL, Long PM, Jazaeri A, Martiat P, Fox SB, Harris AL, Liu ET: Breast cancer classification and prognosis based on gene expression profiles from a population-based study. Proc Natl Acad Sci USA 2003, 100:10393-10398.

18. Bakshi RP, Galande S, Muniyappa K: Functional and regulatory characteristics of eukaryotic type II DNA topoisomerase. Crit Rev Biochem Mol Biol 2001, 36:1-37.

19. The World Health Organization: Histological typing of breast tumors. Neoplasma 1983, 30:113-123.

20. Tuczek HV, Fritz P, Oeffinger B, Limbach HJ, Mischlinski A, Klein C, Wegner G: Interpretation of the estrogen receptor content of breast cancer. Geburtshilfe Frauenheilkd 1990, 50:314-318.

21. Sandri MI, Hochhauser D, Ayton $P$, Camplejohn RC, Whitehouse R, Turley H, Gatter K, Hickson ID, Harris AL: Differential expression of the topoisomerase II alpha and beta genes in human breast cancers. Br J 1996, 73:1518-1524.

22. Hortobagyi GN: Treatment of breast cancer. N Engl J Med 1998, 339:974-984.

23. Rudolph P, MacGrogan G, Bonichon F, Frahm SO, de Mascarel I, Trojani M, Durand M, Avril A, Coindre JM, Parwaresch R: Prognos- 
tic significance of $\mathrm{Ki}-67$ and topoisomerase llalpha expression in infiltrating ductal carcinoma of the breast. A multivariate analysis of $\mathbf{8 6 3}$ cases. Breast Cancer Res Treat 1999, 55:61-71.

24. Jarvinen TA, Tanner M, Rantanen V, Barlund M, Borg A, Grenman $\mathrm{S}$, Isola J: Amplification and deletion of topoisomerase Ilalpha associate with ErbB-2 amplification and affect sensitivity to topoisomerase II inhibitor doxorubicin in breast cancer. $\mathrm{Am} \mathrm{J}$ Pathol 2000, 156:839-847.

25. Asano T, An T, Mayes J, Zwelling LA, Kleinerman ES: Transfection of human topoisomerase II alpha into etoposide-resistant cells: transient increase in sensitivity followed by down-regulation of the endogenous gene. Biochem J 1996, 319:307-313.

26. Petit T, Wilt M, Velten M, Millon R, Rodier JF, Borel C, Mors R, Haegele $P$, Eber M, Ghnassia JP: Comparative value of tumour grade, hormonal receptors, Ki-67, HER-2 and topoisomerase II alpha status as predictive markers in breast cancer patients treated with neoadjuvant anthracycline-based chemotherapy. Eur J Cancer 2004, 40:205-211.

27. Nakopoulou L, Lazaris AC, Kavantzas N, Alexandrou P, Athanassiadou P, Keramopoulos A, Davaris P: DNA topoisomerase IIalpha immunoreactivity as a marker of tumor aggressiveness in invasive breast cancer. Pathobiology 2000, 68:137-143.

28. Akimitsu N, Adachi N, Hirai H, Hossain MS, Hamamoto H, Kobayashi M, Aratani Y, Koyama H, Sekimizu K: Enforced cytokinesis without complete nuclear division in embryonic cells depleting the activity of DNA topoisomerase Ilalpha. Genes Cells 2003, 8:393-402.

29. Akimitsu N, Kamura K, Tone S, Sakaguchi A, Kikuchi A, Hamamoto $\mathrm{H}$, Sekimizu K: Induction of apoptosis by depletion of DNA topoisomerase Ilalpha in mammalian cells. Biochem Biophys Res Commun 2003, 307:301-307.

30. McPherson JP, Goldenberg GJ: Induction of apoptosis by deregulated expression of DNA topoisomerase Ilalpha. Cancer Res 1998, 58:4519-4524. 